\title{
Backing for anti-cloning bill reopens embryo debate
}

[WASHINGTON] The science committee of the US House of Representatives sent a shot across the bows of the biomedical research community last week by endorsing an anticloning bill significantly rewritten to ban the cloning of human embryos - not merely the cloning of 'human beings'.

The decision was the first action on cloning legislation by a congressional committee. It immediately drew complaints that it ignored the recommendations of President Bill Clinton's National Bioethics Advisory Commission, needlessly reopened the debate on human embryo research, and risked restricting beneficial research that used cloning technology but was not aimed at producing cloned humans.

"The US seems hell bent on withdrawal from one of the most important areas of biomedical research," wrote David Blake, vicepresident for biomedical research at the Association of American Medical Colleges, in a message sent on the Internet to advocates of biomedical research. Sean Tipton of the American Society for Reproductive Medicine, agreed: "We are very concerned that this bill, rather than a cloning bill, has become a permanent embryo research ban."

"The debate has now totally changed," says Chuck Ludlam, vice-president for government relations at the Biotechnology Industry Organization (BIO). In a letter to Lynn Rivers (Democrat, Michigan), a Congress science committee member, Ludlam said he feared that Vernon Ehlers (Republican, Michigan) would use the bill as "a vehicle for relitigating the embryo research issue". This is a reference to a perennial debate in the Congress between opponents of abortion, mainly Republican, who seek to outlaw human embryo research, and research advocates, mainly Democrats, who say that such research should be permissible within careful constraints.

Ehlers, a physicist by training, argues that his bill will in fact protect biomedical research

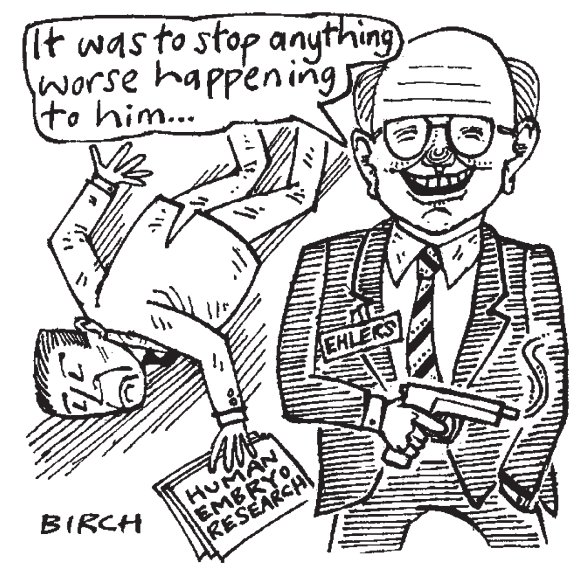

by pre-empting more drastic bills which could lead to a ban on cloning in all research, including animal work. Ehlers told Nature that the rewriting was dictated by political necessity, as a "majority" of science committee members, led by chairman James Sensenbrenner (Republican, Wisconsin), "said they couldn't vote for the bill without also banning cloning of embryos".

The rewritten bill bans federal funding for "any project of research that includes the use of human somatic cell nuclear transfer technology to produce an embryo". When Ehlers first introduced the bill in March, it banned funding for work using "a human somatic cell for the process of producing a human clone".

Most political sympathies in the committee were with the rewritten bill. When Rivers proposed an amendment to restore the ban to one on the use of cloning for "creation of a human being", it was soundly defeated. Another Rivers amendment did pass, protecting the use of cloning technologies to clone molecules, DNA, cells, tissues or cells other than human embryo cells, and to create animals other than humans.

But BIO and others still argue that the bill as passed could jeopardize broad classes of research such as the growth of lines of nerve, liver or kidney cells. The reason, according to $\mathrm{BIO}$, is that in the 'post-Dolly' era, any somatic cell can in theory be "used ... to produce" an embryo. So a scientist working with a cell that could potentially give rise to an embryo could be open to having his intent questioned and possibly fall within the bill's prohibitions.

In addition, the fact that the law would be permanent would create "the worst of all worlds", said Ludlam. President Clinton and the bioethics advisory commission recently supported anti-cloning legislation that does not outlaw the use of embryos to create research embryos if they are not implanted, but that bill would expire after five years.

But what BIO fears most is a second Ehlers bill that applies not to federally funded scientists but to the private sector. That bill, now before the House of Representatives commerce committee, seeks a $\$ 5,000$ penalty for anyone, public or private, attempting to produce a 'human clone'. Ehlers has not rewritten the bill to penalize the cloning of a human embryo, but may yet make such a change.

Federal funding for human embryo research is already banned under provisions attached to the spending bills that fund the National Institutes of Health. The Ehlers bill would make the ban permanent for the use of cloning technologies in creating embryos, though not for embryo research not involving cloning.
MeredithWadman

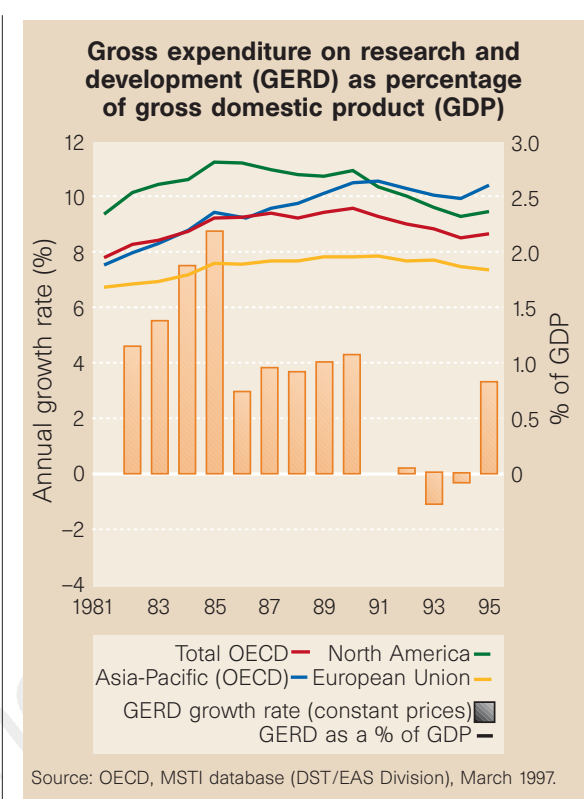

\section{Japan leads rise in research budgets in OECD countries}

[PARIS] Research budgets measured collectively across the world's industrialized countries are increasing again after the economic slump of the early 1990s, according to latest figures from the Organization for Economic Cooperation and Development (OECD).

Between 1994 and 1995, the total spending of the OECD's 27 member states on research and development increased from 2.1 to 2.2 per cent of their joint gross domestic product (GDP), the first increase since 1990, when it peaked at 2.4 per cent ( see chart).

The OECD statistics show that the most research-intensive member states are clearly those in the Asia-Pacific region, particularly Japan which, despite its economic difficulties, spent 2.8 per cent of its GDP on research and development in 1995.

But there has also been a slight upturn in research spending in North America, led by the United States, after an almost continuous decline since the mid-1980s; the OECD warns, however, that forecast data for 1996 "did not suggest continued growth". The European Union's record has been mixed, with overall spending dropping slightly from 1.9 to 1.8 per cent of GDP — between 1994 and 1995.

Among those whose research and development profile the OECD notes has changed significantly, Ireland spent twice the percentage of GDP on research and development in 1995 as in 1981, and recorded high growth rates in expenditure, ranging from 15 to 20 per cent a year, in the 1990s.

Science, Technology and Industry: Scoreboard of Indicators 1997. OECD, Paris. FF200. ISBN: 92-64-15507-4 